\title{
Speech Act of Greeting for American Native Speakers of English and Saudi Native Speakers of Arabic: A Comparative Study
}

Rehan Almegren*

Department of English, French and German, Faculty of Humanities, University of Málaga, Campus de Teatinos, 29071 Málaga, Spain

Corresponding Author: Rehan Almegren, E-mail: rehanmeg@gmail.com

\section{ARTICLE INFO}

\section{Article history}

Received: June 09, 2017

Accepted: August 22, 2017

Published: December 01, 2017

Volume: 6 Issue: 7

Special Issue on Language \& Literature Advance access: September 2017

Conflicts of interest: None Funding: None

\begin{abstract}
This study focuses on comparing the speech acts of native Arabic speakers of Saudi region and English speakers of America, which help depict the impact of the variables involved, namely status, setting, social distance and situation formality. This paper makes a significant contribution for future researchers, as it is of help to researchers in the speech act area specifically in terms of Saudi Arabic and American English. It will be also of help to those learning Arabic or English and those who teach it in these two countries. Thus, the outcome of this research will contribute to depict the differences and the similarities in the use of greeting strategies between two different groups of respondents from diverse linguistic and cultural domains. Data was collected using the discourse completion test (DCT), developed by Cohen, Olshtain \& Rosenstien (1985). Fifty female respondents within the age group of 20-25 years were selected from each group to participate in research procedures. Although the inclusion of male respondents would have made the process complex, it would have provided with comparatively more accurate outcomes if managed properly. The findings showed that linguistic and cultural differences, variables of social distance, social status, settings and situation formality greatly influenced the decisionmaking of Saudi Native Speakers of Arabic and American Native Speakers of English, pertaining to their usage of greeting strategies as part of their speech acts. For example, differences can be observed between these two speakers in terms of their greeting strategies; American English speakers attach less significance to social and physical distance and hierarchy compared to Saudi Arabic speakers. Similarly, both the groups attach almost equal importance to their initiation words when greeting others. These differences and similarities help determine social status and the relationship between speakers.
\end{abstract}

Key words: Pragmatics, Politeness Strategies, Speech Act, Greeting, DCT

\section{INTRODUCTION}

\section{Background of the Study}

The pragmatic concept of the Speech Act Theory was introduced in research papers in 1962, developed by Austin (1962) and further explored by his student, Searle (Al-Hindawi, Al-Masu'di, \& Fua'd Mirza, 2014). Greeting strategies are mostly found to be prime "access rituals" in communication processes, as they facilitate initiating a conversation (Meiirbekov, Elikbayev, Meirbekov, \& Temirbaev, 2015, p. 268).

Greeting is an essential factor of social interaction which develops and maintains interpersonal relationships (Wei, 2010). Moreover, the modes used for greetings constitute significant linguistic mechanisms, helping the greeter to reflect their attitude and impression of their relationship with the speaker. Social relationships between both speakers and listeners pertaining to their social distance and status are also depicted from their usage of the greetings strategy (Ahmad, 2015). Individuals from different linguistic backgrounds use varied greeting strategies for interaction, which might prove to be similar for certain groups of people while remaining different for the others. These differences and similarities also portray the means through which social relationships are determined when portraying linguistic and cultural differences among groups (Meiirbekov et al., 2015).

According to Altbach (2002), over 1.6 million students now cross borders to study at higher learning institutions in a concept known as the globalisation of education. Even among the Arabian population, much attention is paid to speech acts in English. One of the important perspectives that needs to be noted while translating Arabic into other languages such as English is the Iltifat speech act (shifting), which makes Arabic unique, complicated and different from other languages.

Completion of this research helps native Arabic and English speakers to gather in-depth knowledge of the minute aspects related to speech acts, enabling them to enhance their skills of social communication, despite pertaining to diverse cultures. 


\section{Research Contexts}

The context focussed on this research paper is centred on the sociolinguistic characteristics of greetings as a speech act along with the differences and similarities evident in the case of the Arabic and English languages. The result of the comparative studies entails clear inference of the similarities evident in the implementation of greeting strategies between two different linguistic and cultural backgrounds. Furthermore, the paper examines the impact of the main factors, namely social distance, situation formality, status and setting on the selection of greeting strategies by the native English and native Arabic speakers.

\section{LITERARY REVIEW}

This literary review section reviews previous bodies of research as conducted by recognised scholars on identified issues. The Politeness Theory proposed is the theoretical framework, based on which the research was conducted. This concept primarily refers to the behaviour of an individual that can be depicted from his/her face and face work. It originated from the Chinese perspective of 'face', which reflected a positive approach towards communication (Vilkki, 2006). Besides, generation, social distance and gender have a large impact on the manner in which the greeting strategy is used irrespective of non-verbal and verbal forms of communication in both the English and Arabic languages.

Pragmatics refers to the process that language users apply to represent a sentence in the grammatical way and as such, the way a sentence is uttered has different effects on what a speaker says (Fraser, n.d.). Chierchia, Fox \& Spector (2008) added that pragmatics has features that influence speech by making assertive statements, but that they do not interfere with the propositional content within speech. The role of pragmatics is to manage conversations. They are features of speech which do not generally contribute to the propositional content of communication but which have important functions in the way that we manage our conversations. Bach (2003), claimed that Austin (1962), who came up with the theory of the speech act, classified it into three divergent acts: perlocutionary, elocutionary and illocutionary acts. Social status and social distance are some of the differing variables that influence communication between two partners (Buchan, Johnson \& Croson, 2006). The Linguistic Politeness Research Group (2011) added that the dimension of politeness theory is another relevant theory in the communication process as social distance, the stature of imposition, and power relationship considerations are examined. Limberg (2008) asserts that politeness is a normative way of moral order intervening between individual communicants. Jalilifar (2009) used Brown and Levinson's theory to contrast the transparency of illocutionary actions in Face Threatening Acts (FTA).

There is the different realisation of politeness among diverse cultures; therefore there is a need to examine the politeness strategy used by foreign language speakers in contrast to native speakers. The initiative must, therefore, involve the collection of data to identify the similarities and differences based on the response to politeness (Thorpe, Snell, Davey-Evans, \& Talman, 2017, p. 32). It is clear that at some point in time there is variance in terms of frequency and performance. In this regard, the present review included the politeness strategies of Jordanian Arabic speakers and American English speakers. Cross-linguistic culture was present extensively, and it is evident that there is cross-cultural variance in speech act performance based on different communities

The depiction of a behavioural characteristic through the face and facial expression is the aspect in which effective strategies are in place to determine politeness. The speech theory, as laid down by Austin (1962), stipulates that many utterances and named speech are a communication of information, but also the performance of an action. Illocutionary force is the extent to which speech acts depict that which is being executed. They are both rule-governed and meaningful. This is the precept on which knowledge in this regard enhances the linguistic competence of an individual.

Marquez-Reiter (2000) describe politeness as being conventionalised, pre-patterned and tied to a standard of communication situation, while according to Coulmas (1981), politeness is consideration for others regarding feelings in terms of their treatment in an interaction (7-11). In the case at hand, there is an elaborate investigative strategy regarding Jordanian native Arabic speakers JNS and American English native speakers. The aim of the study is to show intercultural pragmatic well-being as illustrated in literature. JNS' expression of thanks, apologies, and congratulations together with ANS were focused on, together with a consideration of the similarities and differences that exist between ANS and JNS.

JNS appeal to God was eminent in responses, since religion is the primary influence on interaction in Arabic. Almost all social contexts of politeness in JNS are signified through religion. Greeting, invitation, disagreement, agreement, apology or blame is a show of the proliferated religion and a shows a strong contrast between Arabic and English. It was deduced that the use of religious references in the politeness formula, mainly offering and appealing to God, was the most used strategy in JNS. There is evidence that JNS were also showing gratitude in the form of 'thank you,' but at the end of the same statement, there is the appeal to God for the provision of the person from whom the services were received.

Acknowledgment, acceptance and returning were not commonly used in JNS and ANS. As was shown, JNS have the capability of ensuring they have diverse strategies compared to their counterparts. There is the use of thanks, expressions of joy, notice and attendance, metaphoric use, formulaic non-use, humility, dismissal, thanking and returning. Achievement of interactive goals is mainly based on the strategies that are applicable since there is the tendency of a culture attaching a formulaic meaning which is the opposite of the surface meaning. There is also the tendency that with a formula one would feel offended at the remark unless a sympathetic feeling exists towards the utterance, which includes learned aspects of culture.

Native language transfer does not depict the differences and similarities of the target culture and the indigenous 
culture. There might be a lack of knowledge regarding the extent in which the variance exists, and there is the probative attribute that the native speaker might react to unacceptable behaviour which might be the norm for the indigenous culture. The likelihood of attributing pragmatic failures to personal flaws and ethno-cultural origins has adverse social impacts.

Politeness is intuitive or text perceived if it was built in recent empirical methods. Ethno-cultural methodology along with speech theory guarantees success in politeness research. It is thought that acquisition of the first language depict politeness formula is the training model parents exercise to teach their children language. As teachers are responsible for training, they must ensure students are well acquainted with the formulas to produce the common command and linguistic idiosyncrasies of a given language. Politeness demands acquisition, as well as an acute feeling for a language and for the community speaking that language. Effective speaking of a language does not only demand linguistic competence but also the presence of competence that is community backed.

Teaching of formula expressions is the only way in which there has been an attempt to ensure that there is the production of polite non-native speakers. Since politeness is an incorporation of feeling towards a language, there is a propensity towards the language being inappropriate. There will be a considerable reduction of the chances of learning a language if the interested individual is met with indifference, coldness or aggression.

Creation of communication competence is mainly based on pragmatic competence, and a grammatically proficient learner does not have the same pragmatic competence. There is a tendency to appear uncultured, rude or awkward when, despite the appropriate language use, there is a deviation from the pragmatic norms of the target language as outlined by Sharifian (2004). The reliance on textbooks is also brought into contention by Bardovi-harlig and Mahan-Taylor (2003) who claim that textbooks are always not reliable in terms of pragmatic inputs in a class of language learners. The main reason is the general notion that textbook content can come across as rude or odd by native speakers.

All in all, there is the need to consider the complex differences between JNS and ANS regarding the availability of total, partial or absence of equivalence in a given language which causes a learner problems. More appropriate use of the language at hand demands the avoidance of direct transfer of literal translation which may prompt misjudgement, misunderstanding and be considered insincere, odd or impolite.

\section{RESEARCH AIMS AND OBJECTIVES}

This research paper aims at evaluating similarities and differences between the speech acts of American English Speakers (AES) and Saudi Arabic Speakers (SAS) based on their usage of greeting strategies. In accordance with this aim, the following research objectives are structured:

1. Evaluating the greeting strategies used by SAS

2. Assessing the usage of greeting strategies by American native speakers of English
3. Identifying the similarities in greeting strategies used by both the groups

4. Categorizing the differences in the strategies used by both groups for greeting

5. The impact of speech act variables in the selection of greeting strategies

The following research questions are answered to address the determined objective:

1. What are the similarities in greeting strategies between Saudi native speakers of Arabic and American native speakers of English?

2. What are the differences in greeting strategies between Saudi native speakers of Arabic and American native speakers of English?

3. Are social distances, status, settings and situational formalities significant factors in choosing a greeting strategy?

\section{METHODS}

\section{Research Design}

The paper adopted a mixed approach, including qualitative and quantitative methods for accomplishing the targeted aim. Interpretational philosophy was considered for this study, as it primarily deals with the meaningful attributes associated with human nature and their perceptions regarding a particular issue (Chowdhury, 2014). The paper also used an inductive approach to derive a reliable outcome and provide valid answers for research questions. A pilot study was undertaken to ensure the reliability of the questions.

The study also comprised the use of DCT design to question the respondents from both the groups about their reactions based on the nine situations provided to them (refer to Appendix). Names of the characters presented in the situation were modified for the native Arabic speakers with the entire scenario being the same for both groups except for situation number 7 . In this scenario, the setting was changed from a coffee shop to a party for cultural reasons. The situations were designed so as not to bore the respondents and also to stimulate them to complete the procedures effectively. The questionnaire was also prepared in two different languages for the convenience of the respondents in both the native groups. Moreover, the selection of the respondents considered only females, so as to allow detailed and specific data. The DCT design has been illustrated in Table 2, which clearly shows the use of varied settings, status, formality and social distance between the speaker and the hearer in all nine situations.

\section{Data Collection}

The instruments used for gathering the primary data are a Personal Information Questionnaire and a Discourse Completion Test (DCT). The DCT was first used by Blum-Kulka (1982), based on which the speech of a particular group of respondents can be easily determined from their reactions to different situations. The different elements of the speech act, especially to greetings (verbal and non-verbal), were exam- 
ined after the completion of this test. The personal information questionnaire was distributed among female students, 20-25 years-old, at Penn State University, USA and Princess Nourah bint Abdulrahman University in Saudi Arabia. The reason behind the selection of only female respondents was that it would help in providing precise information of the greetings strategy used by females, which would have resulted in general results otherwise. A total of 100 respondents were selected for the survey procedure, among which 50 were American English native speakers and the rest were Saudi Arabic native speakers. The respondents also had to do a DCT, where they were provided with nine case scenarios and had to write down how they would have reacted if they had been present. All the scenarios comprise different variables of the speech acts such as Setting, Situation Formality, Status and Social Distance.

\section{Data Sources}

The research paper has adopted several strategies or techniques to provide a comparative study of the greeting speech acts used by the AES and the SAS groups. Data used for the research and collected from the personal information questionnaire and DCT are illustrated in Table 1 and 2 below.

\section{Data Analysis}

The Statistical Package for Social Science (SPSS) Program was used for recording the collected data and for deriving the quantitative findings on the frequency of greeting strategies used by the selected respondents along with the frequency of describing by the sample members.

Furthermore, the MAXQDA10 program was used in the research for analysing the gathered data. With this program, nine documents were configured of group responses from each of the selected groups. Besides, the frequencies and number of words used by each group were extracted from the total of 18 collected documents. The words were segmented based on the types of greeting strategies and again the frequencies were evaluated correspondingly. The findings of the study were then interpreted through charts and graphs.

\section{ETHICAL CONSIDERATIONS AND LIMITATIONS OF THE STUDY}

Ethical standards were considered from the initial phase of data collection, wherein the respondents were informed about the survey procedure. Prior consent was taken and was the students were given complete freedom to voluntarily participate or exit from the process. The identity and the responses of the interested respondents were also kept completely confidential. Approval for carrying out the survey procedure at the universities was obtained from the pertinent authorities.

In spite of maintaining the reliability and validity of the research process to the optimum level, certain limitations could still be witnessed. One such limitation is the gender-bias found in the entire research process, as only females were selected. Another limitation may have been the length of the questionnaire, which could have affected students' ability to answer appropriately.

\section{FINDINGS AND DISCUSSIONS}

This section focuses on producing the data retrieved from both the sources together with the analysis to accomplish the research objectives and answer the research questions.

\section{Quantitative Findings and Discussions}

A total of 3,177 words were spoken by SAS for greeting their

Table 1. Data collected from personal information questionnaire

\begin{tabular}{llllllll}
\hline Group & Gender & Age & $\begin{array}{l}\text { Native } \\
\text { language }\end{array}$ & $\begin{array}{l}\text { Parents' native } \\
\text { language }\end{array}$ & $\begin{array}{l}\text { Participant's } \\
\text { and parents' } \\
\text { nationality }\end{array}$ & $\begin{array}{l}\text { Familiar language } \\
\text { other than native } \\
\text { language }\end{array}$ & $\begin{array}{l}\text { Had not spend more } \\
\text { than a year outside } \\
\text { their home country }\end{array}$ \\
\hline SAS & Female & $20-25$ & Arabic & Arabic & Saudi & No & No \\
AES & Female & $20-25$ & English & English & American & No & No \\
\hline
\end{tabular}

Table 2. Data collected from discourse completion test (DCT)

\begin{tabular}{lllll}
\hline & Setting & $\begin{array}{l}\text { Situation } \\
\text { formality }\end{array}$ & Status & Social distance \\
\hline 1 & University & Formal & Low to high & Student to prof \\
2 & House door & Informal & Equal status & Sister of the participant's friend \\
3 & School & Formal & High to low & Teacher to student \\
4 & University & Informal & Equal status & Best friends \\
5 & Party at friend's house & Informal & Low to high & Friend's mother \\
6 & Own house party & Informal & Old to young; High to low & Friend of the participant's sister \\
7 & Party for Arabic; coffee shop for English & Informal & Equal status & Classmates \\
8 & School & Formal & Low to high; equal status & Student to teacher and classmate \\
9 & University & Formal & High to low & Student librarian to student \\
\hline
\end{tabular}


listeners, which was fewer than the 4,232 words spoken by AES (Table 3). These results were different for the respondents of SAS group, who had spoken the highest number of words for the $3^{\text {rd }}$ situation (485) and the least for $6^{\text {th }}$ situation (203), both lower than the AES groups (Table 4). Duranti (1997) stated that besides cultural differences, the differences in status of communicators and settings also have an impact on the words being produced by speakers (Figure 1).

A rise in status increases the number of words used by an individual for greeting, which also shows that an individual with a lower status remains controlled and utters comparatively fewer words (Figure 1). Hence, the respondents from both groups had commonness in these preferences. This can further be understood through the $9^{\text {th }}$ situation, where respondents were asked to speak to a younger student. In this situation, both groups followed similar patterns. However, the number of words used by SAS was higher than AES, as social status has an immense impact on language usage (Ahmad, 2015).

The words used by the selected respondents in all nine situations (see Appendix) were categorised into three strategies, namely body language, oral speech and others. AES respondents used body language a total of 114 times, whereas the SAS group used it only 71 times (Table 5). In the case of the oral speech, initiation words were used by majority of the respondents (350 AES and 344 SAS students). The AES participants present in their native setting expressed higher level of confidence in using oral greeting strategies. However, the SAS respondents were lacking in confidence when it came to using such strategies.

Initiation words and occasion words were ranked $1^{\text {st }}$ and $6^{\text {th }}$ by both the groups, while the other rankings were completely different. The AES respondents used Terms of address after initiation words, while SAS respondents used interrogative sentences. Exactly the opposite instance was found in the $3^{\text {rd }}$ rank, where AES placed the interrogative sentences and SAS placed Terms of address. Similarly, the $4^{\text {th }}$ and $5^{\text {th }}$ rankings of AES students were politeness strategies and declarative sentences, while the opposite was preferred by SAS students. Sharifian (2004) solely concentrates on modesty as a core aspect of the Iranian culture, revealing the manner in which the Iranian culture influenced the greeting speech acts of the Persian speakers when using English. The findings obtained with regards Terms of address and body language strategies used by the SAS and the AES groups in this study, supports this notion (Sharifian, 2004).

In Situation 1 (see Appendix), respondents were asked to communicate with their female professor, where the majority of SAS students preferred to use oral speech. However,

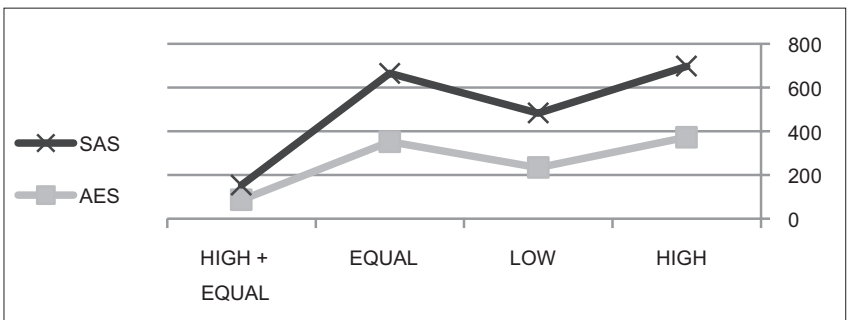

Figure 1. Number of words used by the groups based on status
Kirdasi \& Cheng (2013) stated that Arabic speakers mostly use body language for interacting with those from higher social status. In this case, the similarity in gender can be considered the reason behind the contradicting results, since a female student interacting with a female professor might have boosted their confidence. A higher amount of similarities was found in the usage of greeting strategy between the

Table 3. Total number of words (individual) used by selected respondents

\begin{tabular}{lccc}
\hline Group & $\begin{array}{c}\text { Total number } \\
\text { of words } \\
\text { produced }\end{array}$ & $\begin{array}{c}\text { Highest } \\
\text { number } \\
\text { by a single } \\
\text { participant }\end{array}$ & $\begin{array}{c}\text { Lowest number } \\
\text { by a single } \\
\text { participant }\end{array}$ \\
\hline SAS & 3177 & 36 & 1 \\
AES & 4323 & 43 & 1 \\
\hline
\end{tabular}

Table 4. Total number of words (groups) used by selected respondents

\begin{tabular}{lccccc}
\hline & \multicolumn{2}{c}{ AES } & & \multicolumn{2}{c}{ SAS } \\
\cline { 2 - 3 } \cline { 6 - 6 } & SIT & Words & & SIT & Words \\
\hline First & S4 & 607 & & S3 & 485 \\
Second & S1 & 537 & & S2 & 411 \\
Third & S5 & 533 & & S9 & 396 \\
Fourth & S3 & 509 & & S5 & 385 \\
Fifth & S9 & 465 & & S1 & 372 \\
Sixth & S8 & 452 & & S4 & 352 \\
Seventh & S7 & 419 & & S7 & 288 \\
Eighth & S6 & 417 & & S8 & 285 \\
Ninth & S2 & 384 & & S6 & 203 \\
\hline
\end{tabular}

Table 5. Usage of overall greeting strategies by the selected groups of respondents

\begin{tabular}{|c|c|c|}
\hline \multirow[t]{2}{*}{ Categories } & \multicolumn{2}{|c|}{$\mathbf{N}(\%)$} \\
\hline & AES & SAS \\
\hline \multicolumn{3}{|l|}{ Body language } \\
\hline Total & $114(11)$ & $71(7)$ \\
\hline \multicolumn{3}{|l|}{ Oral Speech } \\
\hline Oral speech $\backslash$ Declarative sentences & $26(2)$ & $61(6)$ \\
\hline Oral speech \Initiation words & $350(33)$ & $344(36)$ \\
\hline Oral speech Interrogative sentences & $180(17)$ & $216(23)$ \\
\hline Oral speech $\backslash$ Occasion phrases & $3(0)$ & $8(1)$ \\
\hline Oral speech $\backslash$ Politeness strategies & $89(9)$ & $49(5)$ \\
\hline Oral speech $\backslash$ Terms of address & $234(22)$ & $157(16)$ \\
\hline Total & $882(84)$ & $835(88)$ \\
\hline \multicolumn{3}{|l|}{ Others } \\
\hline Others $\backslash$ Bringing gift & $0(0)$ & $12(1)$ \\
\hline Others \Conditional sentences & $27(3)$ & $10(1)$ \\
\hline Others\Ignoring & $17(2)$ & $23(2)$ \\
\hline Others\Non-initiation & $6(1)$ & $1(0)$ \\
\hline Total & $50(6)$ & $46(4)$ \\
\hline
\end{tabular}


native English and Arabian speakers (Table 7). The difference between the groups was that politeness strategies were used more by AES students and ranked $5^{\text {th }}$, while SAS students ranked them $6^{\text {th }}$.

From Table 8 below, it can be inferred that the use of other greeting strategies were quite different between groups. AES participants used other greeting strategies while interacting in Situation 1, which was absent for SAS respondents. The first preference of both the groups when using other strategies was conditional sentences. The AES group also used other strategies such as ignoring, non-initiation and bringing gifts, while the SAS respondents were used conditional sentences only. Similar to the findings of Vahid Dastjerdi \& Nasri (2012), it was observed in the results of this research that social distance and power constituted com-

AQ1 Table 6. Usage of oral greeting strategies by the respondents

\begin{tabular}{lll}
\hline Ranking & AES & SAS \\
\hline First & Initiation words & Initiation words \\
Second & Terms of address & Interrogative sentences \\
Third & Interrogative sentences & Terms of address \\
Fourth & Politeness strategies & Declarative sentences \\
Fifth & Declarative sentences & Politeness strategies \\
Sixth & Occasion phrases & Occasion phrases \\
\hline
\end{tabular}

Table 7. Ranking of the usage of oral greeting strategies in situation

\begin{tabular}{lll}
\hline Ranking & AES & SAS \\
\hline First & Initiation words & Initiation words \\
Second & Interrogative sentences & Interrogative sentences \\
Third & Terms of address & Terms of address \\
Fourth & Declarative sentences & Declarative sentences \\
Fifth & Politeness strategies & Occasion phrases \\
Sixth & Occasion phrases & Politeness strategies \\
\hline
\end{tabular}

Table 8. Ranking of the usage of other greeting strategies in situation 1

\begin{tabular}{lll}
\hline Ranking & AES & SAS \\
\hline First & Conditional sentences & Conditional sentences \\
Second & Ignoring & - \\
Third & Non-initiation & - \\
Fourth & Bringing gift & - \\
\hline
\end{tabular}

Table 9. Ranking of the usage of other greeting strategies in situation 2

\begin{tabular}{lll}
\hline Ranking & AES & SAS \\
\hline First & Conditional sentences & Bringing gift \\
Second & - & Ignoring \\
Third & - & Non-initiation \\
Fourth & - & Conditional sentences \\
\hline
\end{tabular}

monness between the AES and SAS groups. Considering the stated factors, it can be inferred that students from both the groups made similar choices in the usage of oral strategies, at least in their first 4 strategies, but were found to be different after that.

Situation 2 (see Appendix) describes the setting of friend house, where the respondents interacted with their friend's younger sister. In this case, the majority of the SAS group were found to use other forms of greetings, while the AES used oral strategies more confidently, which demonstrates the difference in greeting strategies used by the groups (Table 9). The AES respondents used only conditional sentences to address their friend's sister, while it was the last option selected by SAS respondents, as they mostly preferred to bring gifts, ignore or use non-initiation words.

Oral strategies used by the respondents from two diverse groups of natives also possessed vast differences within them (Table 10)

The third situation illustrates a scene, where the respondent is an English teacher and needs to interact with one of her female students aged 17. The AES students used body language, while the SAS students opted for using oral strategies (Table 11 and 12 respectively). Hence, when communicating with a second pair part of comparatively lower social status or age, AES and SAS groups use a common approach of interaction.

Table 10. Ranking of the usage of oral greeting strategies in situation 2

\begin{tabular}{lll}
\hline Ranking & AES & SAS \\
\hline First & Terms of address & Initiation words \\
Second & Initiation words & Interrogative sentences \\
Third & Interrogative sentences & Terms of address \\
Fourth & Politeness strategies & Declarative sentences \\
Fifth & Occasion phrases & Politeness strategies \\
Sixth & Declarative sentences & Occasion phrases \\
\hline
\end{tabular}

Table 11. Ranking of the usage of oral greeting strategies in situation 3

\begin{tabular}{lll}
\hline Ranking & AES & SAS \\
\hline First & Interrogative sentences & Interrogative sentences \\
Second & Initiation words & Initiation words \\
Third & Terms of address & Terms of address \\
Fourth & Occasion phrases & Occasion phrases \\
Fifth & Politeness strategies & Politeness strategies \\
Sixth & Declarative sentences & Declarative sentences \\
\hline
\end{tabular}

Table 12. Ranking of the usage of other greeting strategies in situation 3

\begin{tabular}{lll}
\hline Ranking & AES & SAS \\
\hline First & Ignoring & Ignoring \\
Second & Conditional sentences & Conditional sentences \\
Third & Non-initiation & Non-initiation \\
Fourth & Bringing gift & Bringing gift \\
\hline
\end{tabular}


The $4^{\text {th }}$ situation presented was the interaction pattern of respondents with their best friends, who they meet after a semester break. A higher level of commonness was found in the use of greeting strategies among both the selected groups (Table 13). The differences between the groups were evident in the placement of the options, terms of address, initiation words and interrogative sentences were ranked in the first three positions (Table 14). The results again here meet the findings of the research by Vahid Dastjerdi \& Nasri (2012). The perspective of power as well as social status can be considered responsible for the differences as well as the similarities in the usage of expressions between the AES and SAS groups. A similar approach was found in the study by Hashemian (2008), where the selection of the oral greeting strategies could have been influenced by the social distance and cultural differences.

Respondents need to interact with their friend's mother at a friend's house in the $5^{\text {th }}$ situation. In this case, a wider range of differences were evident in the usage of greeting strategies between the groups, as the AES groups tended towards other strategies. The differences were evident in the usage of terms of address, interrogative sentences, politeness strategy and declarative sentences by the two groups of respondents (see Table 15). The difference could also be found the usage of other strategies, where the AES respon-

Table 13. Ranking of the usage of oral greeting strategies in situation 4

\begin{tabular}{lll}
\hline Ranking & AES & SAS \\
\hline First & Terms of address & Initiation words \\
Second & Interrogative sentences & Terms of address \\
Third & Initiation words & Interrogative sentences \\
Fourth & Declarative sentences & Declarative sentences \\
Fifth & Politeness strategies & Politeness strategies \\
Sixth & Occasion phrases & Occasion phrases \\
\hline
\end{tabular}

Table 14. Ranking the usage of other greeting strategies in situation 4

\begin{tabular}{lll}
\hline Ranking & AES & SAS \\
\hline First & Conditional sentences & Bringing gift \\
Second & - & - \\
Third & - & - \\
Fourth & - & - \\
\hline
\end{tabular}

Table 15. Ranking of the usage of oral greeting strategies in situation 5

\begin{tabular}{lll}
\hline Ranking & AES & SAS \\
\hline First & Initiation words & Initiation words \\
Second & Terms of address & Interrogative sentences \\
Third & Interrogative sentences & Terms of address \\
Fourth & Declarative sentences & Politeness strategies \\
Fifth & Politeness strategies & Declarative sentences \\
Sixth & Occasion phrases & Occasion phrases \\
\hline
\end{tabular}

dents had selected non-initiation words and conditional sentences, while the SAS groups were found to have avoided them completely (Table 16). These differences could largely due to nativelikeness, which was different for both countries. The concept of social status, as mentioned previously in the study of Vahid Dastjerdi \& Nasri (2012), may also points to the reasons behind the dissimilarity in the responses between the AES and the SAS groups at the time of using other greetings strategies in this situation.

The $6^{\text {th }}$ situation depicts the greeting strategy used by the respondents for welcoming their sister's friend at their home for a party. A clear difference was evident in communication pattern and usage of greeting strategies among the groups (refer to Table 18). However, a marked similarity was witnessed in the preference of using oral strategies between the two groups, except with regards the differences in using politeness strategies and declarative sentences (see Table 17). With reference to the study by Al-Khawaldeh (2016), the usage of the politeness theory is considered the main reason behind the majority of the responses being similar, with certain exceptions, in the $6^{\text {th }}$ situation.

The $7^{\text {th }}$ situation describes the scenario of the respondents interacting with an unfamiliar classmate in a café. The AES group inclined more towards the use of body language followed by the use of oral strategies, while the SAS respondents mostly preferred the use of other greeting strategies. The oral strategies used by the groups were largely different

Table 16. Ranking of the usage of other greeting strategies in situation 5

\begin{tabular}{lll}
\hline Ranking & AES & SAS \\
\hline First & Conditional sentences & - \\
Second & Non-Initiation & - \\
Third & - & - \\
Fourth & - & - \\
\hline
\end{tabular}

Table 17. Ranking of the usage of oral greeting strategies in situation 6

\begin{tabular}{lll}
\hline Ranking & AES & SAS \\
\hline First & Initiation words & Initiation words \\
Second & Terms of address & Terms of address \\
Third & Politeness strategies & Declarative sentences \\
Fourth & Declarative sentences & Politeness strategies \\
Fifth & Interrogative sentences & Interrogative sentences \\
Sixth & Occasion phrases & Occasion phrases \\
\hline
\end{tabular}

Table 18. Ranking of the usage of other greeting strategies in situation 6

\begin{tabular}{lll}
\hline Ranking & AES & SAS \\
\hline First & - & Bringing gift \\
Second & - & - \\
Third & - & - \\
Fourth & - & - \\
\hline
\end{tabular}


except in case of the initiation words (Table 19). Similarly, the differences in the usage of other strategies by the groups can be inferred from Table 20, where similarity was evident only in the case of ignoring, indicating the influences of social and cultural factors on their selection of oral speech strategies (Al-Zoumor, 2010).

In the $8^{\text {th }}$ situation, respondents met both their teacher and a classmate at the same time after a week. A higher level of similarity was found in the overall speech acts of both the English and Arabic native speakers. The usage of greeting strategies was common between cultures (Table 21). The difference was evident in the use of declarative sentences, terms of address, occasion phrases and politeness strategies. The commonality is also seen in Table 22, where both groups selected conditional sentences, while the difference was found in the selection of the second most frequently used other strategy. The responses in this context reveal that cultural similarities also denote fewer gaps between the speech acts of the two groups of varying linguistic proficiency (Žegarac \& Pennington, 2000).

Finally, the $9^{\text {th }}$ situation represents the respondents from both AES and SAS groups interacting with a student who regularly visits the library as a volunteer student or a librarian. Although the majority of the SAS students used other greeting strategies, a large number of similarities were found

Table 19. Ranking of the usage of oral greeting strategies in situation 7

\begin{tabular}{lll}
\hline Ranking & AES & SAS \\
\hline First & Initiation words & Initiation words \\
Second & Terms of address & Interrogative sentences \\
Third & Interrogative sentences & Terms of address \\
Fourth & Politeness strategies & Declarative sentences \\
Fifth & Declarative sentences & Occasion phrases \\
Sixth & Occasion phrases & Politeness strategies \\
\hline
\end{tabular}

Table 20. Ranking of the usage of other greeting strategies in situation 7

\begin{tabular}{lll}
\hline Ranking & AES & SAS \\
\hline First & Ignoring & Ignoring \\
Second & Non-initiation & Conditional sentences \\
Third & Conditional sentences & Bringing gift \\
Fourth & Bringing gift & Non-initiation \\
\hline
\end{tabular}

Table 21. Ranking the usage of oral greeting strategies in situation 8

\begin{tabular}{lll}
\hline Ranking & AES & SAS \\
\hline First & Initiation words & Initiation words \\
Second & Interrogative sentences & Interrogative sentences \\
Third & Politeness strategies & Declarative sentences \\
Fourth & Terms of address & Politeness strategies \\
Fifth & Declarative sentences & Occasion phrases \\
Sixth & Occasion phrases & Terms of address \\
\hline
\end{tabular}

in the usage of oral speech and body language between the groups. Similarities in the use of oral strategies were also found in the placing of initiation words, declarative sentences and accession phrases in the $1^{\text {st }}, 5^{\text {th }}$ and $6^{\text {th }}$ position, respectively. The differences were found in the usage of interrogative sentences, terms of address and politeness strategies between the groups (Table 23). Table 24 also provides a clear view of the similarities in the speech acts of both the selected groups of respondents, illustrating the use of conditional sentences and ignoring as their preferential other forms of greeting strategies. No difference was found in this case. This finding also aligns with the explanations in Žegarac \& Pennington (2000) mentioned previously.

\section{Qualitative Findings and Discussions}

The findings provide a clear understanding on the subject area. Considering the data analysis technique of the MAXQDA10 program, small differences exist between the greeting strategies used by the SAS and the AES groups. Analysing the use of declarative strategy, the greeting strategies are somewhat similar for most of the provided situations. For instance, the AES respondents used "it is good to see you", which has a meaning similar to that of "كتيؤرب مديعس" "Iam happy to see you this morning”. Some of the differences that were evident between the groups were

Table 22. Ranking of the usage of other greeting strategies in situation 8

\begin{tabular}{lll}
\hline Ranking & AES & SAS \\
\hline First & Conditional sentences & Conditional sentences \\
Second & Non-Initiation & Ignoring \\
Third & - & - \\
Fourth & - & - \\
\hline
\end{tabular}

Table 23. Ranking of the usage of oral greeting strategies in situation 9

\begin{tabular}{lll}
\hline Ranking & AES & SAS \\
\hline First & Initiation words & Initiation words \\
Second & Terms of address & Interrogative sentences \\
Third & Interrogative sentences & Politeness strategies \\
Fourth & Politeness strategies & Terms of address \\
Fifth & Declarative sentences & Declarative sentences \\
Sixth & Occasion phrases & Occasion phrases \\
\hline
\end{tabular}

Table 24. Ranking of the usage of other greeting strategies in situation 9

\begin{tabular}{lll}
\hline Ranking & AES & SAS \\
\hline First & Ignoring & Ignoring \\
Second & Conditional sentences & Conditional sentences \\
Third & - & - \\
Fourth & - & - \\
\hline
\end{tabular}


the use of "I cannot believe it. It is you Nataly" used by the AES groups and "مدم ذنم كر ا مل, It's been a long time I didn't see you" as used by the SAS group. The comparative study could not be conducted at certain instances such as Situations 2, 3 and 9 due to the absence of responses by AES students, which can be clearly seen in Table 25 below.

The use of initiation words by the respondents of two diverse groups were similar pertaining to their communication patterns. In majority of the situations, both the groups used similar terms such as "Hi" and "Hello" irrespective of the social status or social distances between the communicators. Moreover, the use of initiation word such as "welcome" was evident only within the AES students, but was completely absent in the greeting strategy of the SAS students. Also, the SAS group used the greeting phrase "Asslam Alaykum" which is a religious greeting phrase. Thus, cultural factors were evident in SAS group responses (Table 26).

Addressing a similar issue, Bataineh \& Bataineh (2008) aimed at identifying the basic similarities and dissimilarities during the processing of different languages involving American English and Jordanian Arabic speaking respondents. The examination conducted by Bataineh \& Bataineh (2008), focused on the apology strategies used by these groups, which revealed that while the Arabic speakers had greater inclination towards using explicit manifestations of apology, the native English speakers were more likely to use lesser explicit apology strategies. Moreover, differences were observed on the basis of gender within the group of Jordanian Arabic speakers, possibly owing to social stigma and cultural notions (Bataineh \& Bataineh, 2008). Hence, the possibility that the differences observed in this study between the AES and the SAS students are influenced by the cultural aspects, which becomes apparent, as it clearly affects the construction of dialogues by the two groups in the given situations (Makatchev \& Simmons, 2011).

Analysing the use of interrogative sentences in dealing with the similar situations, the respondents from AES and SAS backgrounds used similar greeting strategies (Table 27). The similarity is understood with the interrogative sentence "how are you" in the majority of the situations. The questions asked by the speakers also proved the commonness between the cultures irrespective of the basic factors of the speech act. No differences between the groups were found to be evident in the use of interrogative sentences.

The use of occasion phrases was different between the two groups due to the variation in the native languages and cultural backgrounds (Table 28). The similarity was found in the meaning of the occasion words "I hope you had a nice break" used by the AES students and "Happy comeback" as used by the SAS respondents. Hence, it can be stated that in all situations, except the $9^{\text {th }}$, the speakers from both the groups had different responses.

A crucial theory in this context can be identified with reference to the study conducted by Munro (1993), whereby the researchers proved that use of acoustic measurements varied among the native English speakers and the native Arabic speakers. This in turn affected their vowel selections and durations when processing messages in English, the frequencies of vowel use and their movement. These factors altogether influence their speech act, with native English speakers depicting greater confidence to use more explicit sentences, as observable in Table 28, while those produced by the Arabic

Table 25. Comparative study of the usage of declarative sentences

\begin{tabular}{|c|c|c|}
\hline Sit & AES & SAS \\
\hline 1 & It is good to see you & 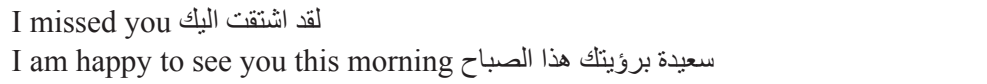 \\
\hline 2 & & 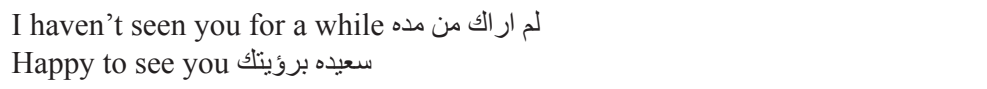 \\
\hline 3 & - & - \\
\hline 4 & $\begin{array}{l}\text { I cannot believe it. It is you Nataly } \\
\text { I have missed you so much }\end{array}$ & 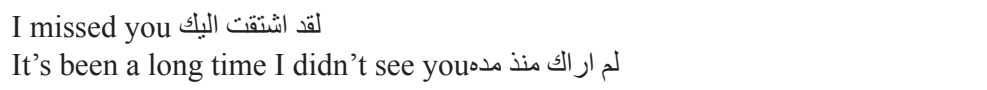 \\
\hline 5 & $\begin{array}{l}\text { I will tell her I am pleased to meet her. } \\
\text { Nice to meet you }\end{array}$ & 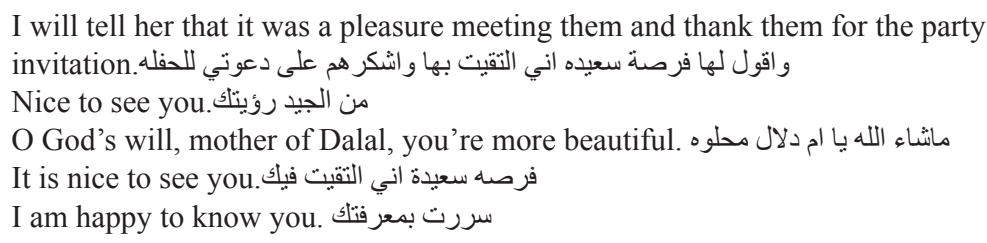 \\
\hline 6 & $\begin{array}{l}\text { Great to see you } \\
\text { Good to see you }\end{array}$ & 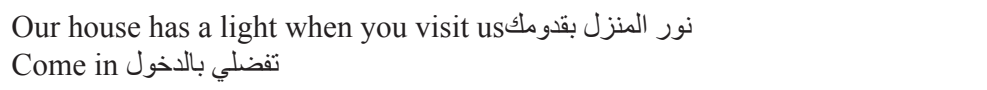 \\
\hline 7 & Nice to see you & 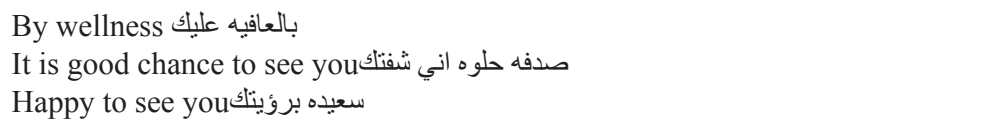 \\
\hline 8 & Good to see you guys & I missed you so much اشتقت لكم كثير \\
\hline 9 & & 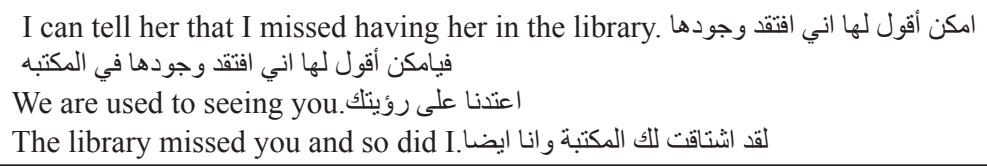 \\
\hline
\end{tabular}


Table 26. Comparative study of the usage of initiation words

\begin{tabular}{|c|c|c|}
\hline Sit & AES & SAS \\
\hline 1 & $\begin{array}{l}\mathrm{Hi} \\
\text { Hello }\end{array}$ & 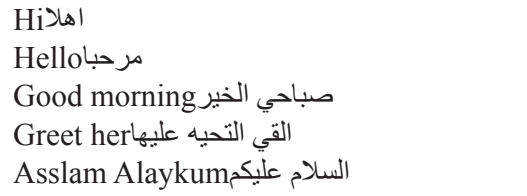 \\
\hline 2 & $\begin{array}{l}\mathrm{Hi} \\
\text { Hello }\end{array}$ & 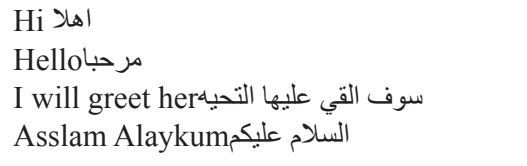 \\
\hline 3 & $\begin{array}{l}\text { Hey } \\
\text { Hello } \\
\text { Good morning }\end{array}$ & 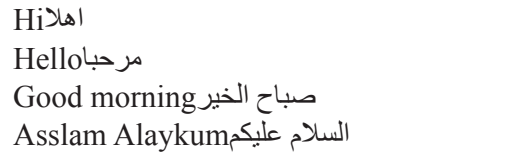 \\
\hline 4 & $\begin{array}{l}\text { Hey } \\
\text { Hello } \\
\text { Good morning }\end{array}$ & 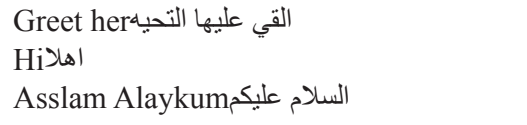 \\
\hline 5 & $\begin{array}{l}\text { Hey } \\
\text { Hello } \\
\text { Greeting } \\
\text { Good evening }\end{array}$ & 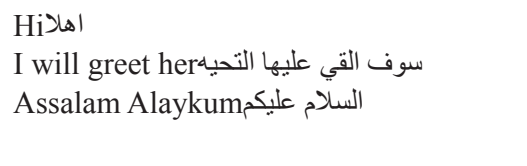 \\
\hline 6 & $\begin{array}{l}\text { Welcome } \\
\text { Hey } \\
\text { Hello } \\
\text { Greet her }\end{array}$ & 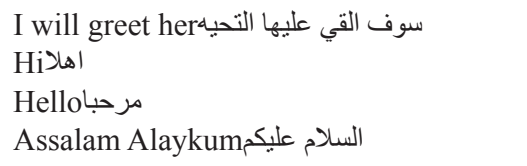 \\
\hline 7 & $\begin{array}{l}\text { Hey } \\
\text { Hello }\end{array}$ & 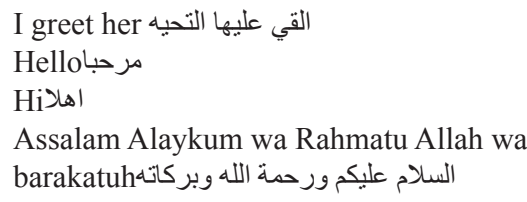 \\
\hline 8 & $\begin{array}{l}\text { Hello } \\
\mathrm{Hi} \\
\text { Greet }\end{array}$ & 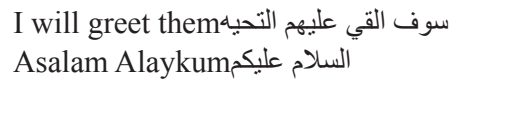 \\
\hline 9 & $\begin{array}{l}\text { Welcome } \\
\mathrm{Hi} \\
\text { Hello }\end{array}$ & 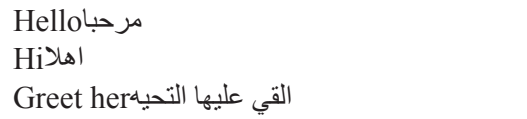 \\
\hline
\end{tabular}

speakers were comparatively less explicit. Similar findings were noted by Flege \& Port (1981) and Flege (1980) while study phonetic interference from Arabic to English.

Based on the politeness theory developed by Brown and Levinson (1987), polite phrases were used by the selected respondents of diverse backgrounds, namely the AES and SAS group (Wagner, 2004). Table 29 shows that similarities are present in most of the situations based on the relevancy theory. Considering this theory, the polite greeting strategies used by AES respondents can be considered similar in meaning to the speech acts of the Arab population (Allott, 2013). Certain differences that were evident within the groups are "tell her I am student in her class" as used by the AES students in the first situation, which does not match with the responses of the SAS students. Similarly, ماذا تأمر واستأذن منها للخروج Would you like something? And then I ask for permission to leave" was used by SAS students in the $5^{\text {th }}$ situation, which is quite different from the expressions of the AES students.

The terms of address used by the groups was common between the cultures, as the terms used by AES respondents were similar to the SAS group (Table 30). In Situations 3, 4, 5 and 6, the SAS group used titles and words that express their relation and emotion while greeting. These were considered as interesting differences that show differences in greeting strategies between the two groups.

TAnalysing the body language of the respondents, the expression "smile" was preferred by both groups in all the situations (Table 31). Hence, the majority of speech acts, in terms of greeting strategies, were common between the cultures of AES and SAS groups. However, the slight differences found within the groups are those such as keeping a physical distance by the AES group and being shy by the SAS students. These responses show the differences between the two groups in this greeting strategy, which is also evident in the findings of Vahid Dastjerdi \& Nasri (2012) and Rababah (2002). In these studies, it was revealed that the differences in certain responses between the groups were the results of social and physical distances between the respondents. It was found to be more in the case of the SAS students than the AES students and hence these had an impact on their 
Table 27. Comparative study of the usage of interrogative sentences

\begin{tabular}{|c|c|c|}
\hline Sit & AES & SAS \\
\hline 1 & $\begin{array}{l}\text { How was your break? } \\
\text { How are you? }\end{array}$ & $\begin{array}{l}\text { How are you? كيف الاجازه معك؟? اخبارك؟كيفك؟ ? كيف حاللك? How are you doing } \\
\text { How was the vacation with you }\end{array}$ \\
\hline 2 & How are you?, what is up? How is it going? & 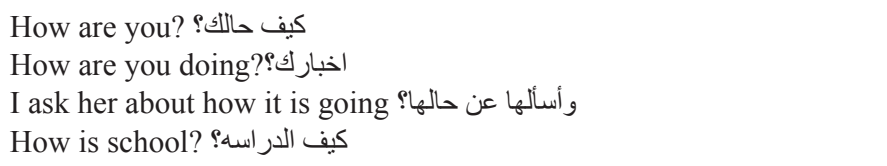 \\
\hline 3 & $\begin{array}{l}\text { How was your exam? } \\
\text { How are you? } \\
\text { Ask how her break was }\end{array}$ & 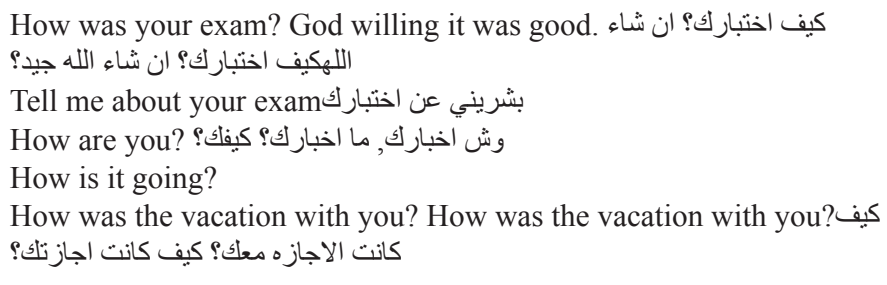 \\
\hline 4 & $\begin{array}{l}\text { How was your break? } \\
\text { How are you? } \\
\text { How she is doing } \\
\text { What is up? }\end{array}$ & 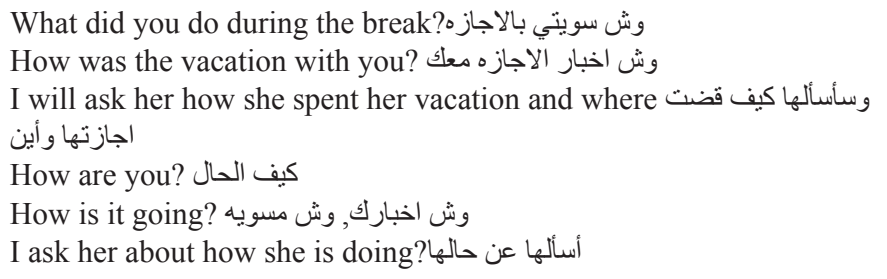 \\
\hline 5 & $\begin{array}{l}\text { How is everything with you? } \\
\text { How are you? }\end{array}$ & 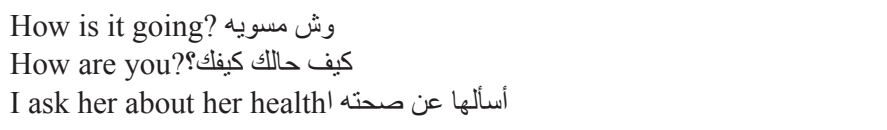 \\
\hline 6 & How are you? How is it going? & 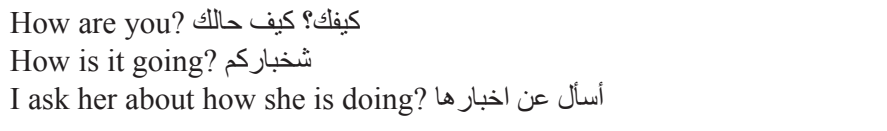 \\
\hline 7 & $\begin{array}{l}\text { How are you? } \\
\text { What is up? }\end{array}$ & 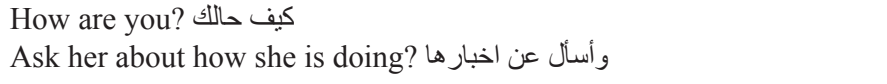 \\
\hline 8 & How are you? What is up? How was your vacation? & 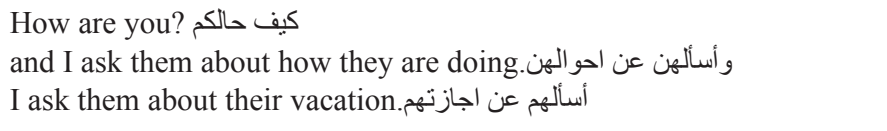 \\
\hline 9 & $\begin{array}{l}\text { How was your vacation? } \\
\text { How are you? } \\
\text { How was your day? } \\
\text { How is the college? }\end{array}$ & 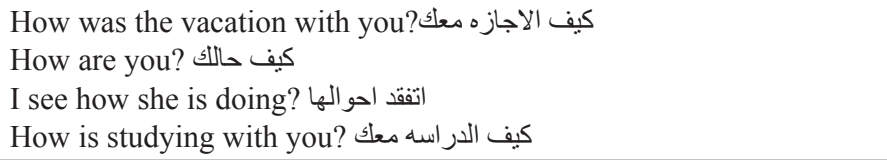 \\
\hline
\end{tabular}

Table 28. Comparative study of the usage of occasion words

\begin{tabular}{|c|c|c|c|}
\hline Sit & Group & The sentences & Frequency \\
\hline 3 & AES & It is good to see you & 1 \\
\hline 8 & SAS & I missed you لقد اشتقت اليك & 6 \\
\hline 9 & SAS & $\begin{array}{l}\text { الصباح سعدت برؤيتلك هذا I } \\
\text { am happy to see you this } \\
\text { morning }\end{array}$ & 2 \\
\hline
\end{tabular}

responses, leading to the differences in their usage of body language. These indicators further denote the significance of the cultural aspects of social distance and power distribution (Vahid Dastjerdi \& Nasri, 2012; Rababah, 2002).

The use of other greeting strategies shows implementation of the relevance theory in analysing the responses of AES as similar to the SAS group. Moreover, the absence of any expression by SAS students in the $3^{\text {rd }}, 4^{\text {th }}, 5^{\text {th }}$ and $6^{\text {th }}$ situations proves that the greeting strategy was different among the groups. According to the relevance theory, speakers are likely to adjust by justifying the contextual assumptions in the given situation to decide upon discarding the statements on which they wish to react and those on which they decide otherwise (Žegarac \& Pennington, 2000).

\section{CONCLUSION}

\section{Summary}

The use of communication strategies helps language speakers to enhance their strategic competence (Toomnan \& Intaraprasert, 2015). The findings derived from collected data point to the fact that both the native English and Arabic speakers showed confidence while interacting with someone from lower social status which in turn increased the number of words uttered by them. However, distinct differences were found in generating words, when analysed from the comparison perspective.

Study findings reveal that the usage of oral strategies were common between groups with differences in the us- 
Table 29. Comparative study of the usage of politeness strategies

\begin{tabular}{|c|c|c|}
\hline Sit & AES & SAS \\
\hline 1 & Tell her I am a student in her class & 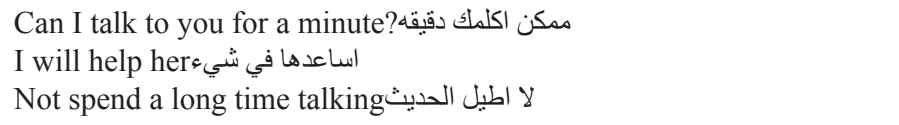 \\
\hline 5 & $\begin{array}{l}\text { Thank you very much for having me in your home } \\
\text { Introduce my self } \\
\text { I would politely and warmly say Hello Mrs. (Last } \\
\text { name) }\end{array}$ & 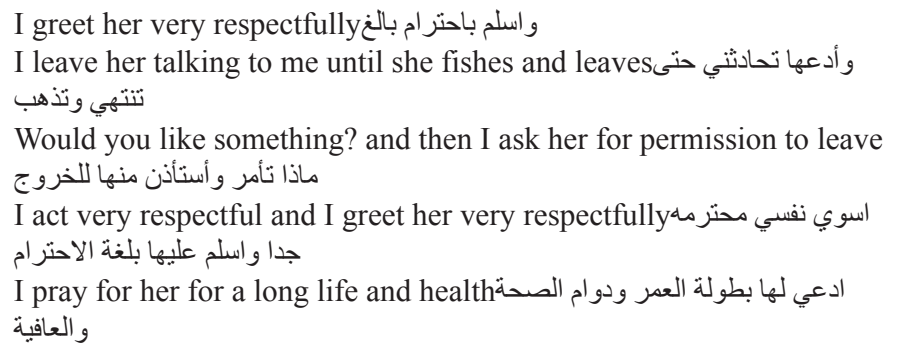 \\
\hline 6 & $\begin{array}{l}\text { Thanks for coming } \\
\text { Please come in } \\
\text { Nice of you to come } \\
\text { Invite her in } \\
\text { The party is this way }\end{array}$ & 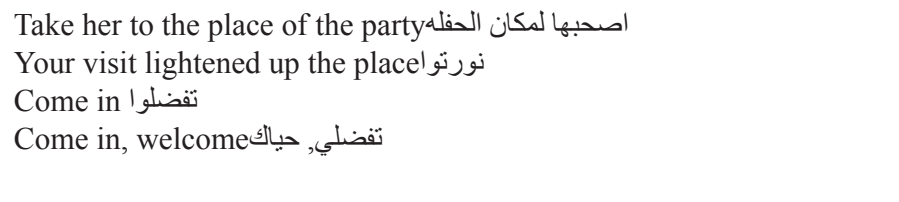 \\
\hline 7 & Introduce myself & I invite her to eat with meادعو ها للأكل معهاe \\
\hline 8 & $\begin{array}{l}\text { Sorry excuse me, I will just wait outside until you } \\
\text { are done } \\
\text { I am wondering if you have a minute to talk }\end{array}$ & $\begin{array}{l}\text { ثم اعتذر و انتظر بالخارج حتى.Apologize and wait outside until they finish بنتهوا من الحديث } \\
\text { I will be respectful بصبر محترمه }\end{array}$ \\
\hline 9 & $\begin{array}{l}\text { What are you looking for today? } \\
\text { What I can do for her } \\
\text { I will ask her if she needs help finding anything } \\
\text { Is there anything I can help you with today? } \\
\text { I would ask her what she was looking for, then take } \\
\text { her to find what ever she needed. } \\
\text { Do you need help }\end{array}$ & 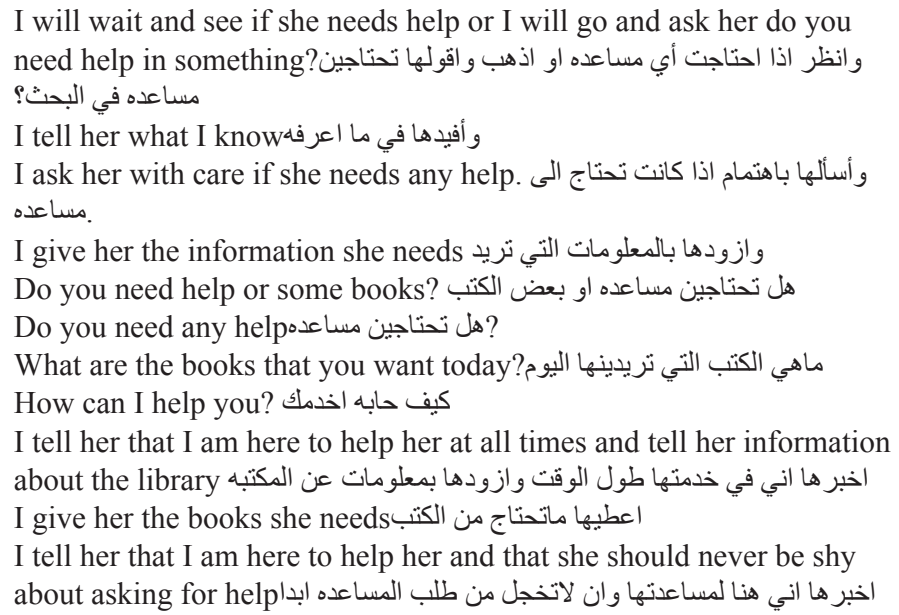 \\
\hline
\end{tabular}

age of other strategies. Arabic speakers tended to use other greeting strategies, while English speakers used oral strategies. Chung (2006) found that Korean bilinguals used code-switching strategy in their communication. Moreover, the findings also depicted the impact of social status on the selection of greeting strategies, as the English native speakers preferred to use body language with the Arabic speakers.

Oral strategies used by both the groups were also similar, while the differences were evident in their usage of other forms of greeting. For English majors in Thailand, Toomnan \& Intaraprasert, (2015) write that motivation is the link between the use of communication strategies and attitudes among English speakers. The study findings showed completely different results for the use of oral strategies and other forms between the two groups of speakers. As Kankaanranta notes, it is a strategy used to build a good social relationship with others to maintain the relationship (cited in Waldvogel, 2007). Similarly, the distinction was found when Ara- bic speakers preferred to bring gifts for the hosts at a party, which was not evident among the English speakers. The impact of social distance and situation formality on the greeting strategies of the two groups of speakers could be inferred from the quantitative findings of the study. Hence, in such a situation, the Arabic speakers preferred to use other forms such as ignoring, while the English speakers mostly opted for the use of body language and oral strategies. The study findings also proved that the selection of overall strategies for greetings was common between both the cultures.

Hua, Nor \& Jaradat (2012) explain that the most frequently used strategy of communication was code switching for interlingual purposes while the least used was word coinage for intralingual purposes. The levels of oral proficiency influence the use of communication strategies; hence, raising awareness among high proficient and low proficient speakers can ease communication (Hua, Nor, \& Jaradat, 2012). The qualitative results primarily denoted that majority of the oral strategies, 
Table 30. Comparative study of the usage of terms of address

\begin{tabular}{|c|c|c|}
\hline Sit & AES & SAS \\
\hline 1 & $\begin{array}{l}\text { Professor Victoria } \\
\text { Professor } \\
\text { Mrs. Victoria }\end{array}$ & 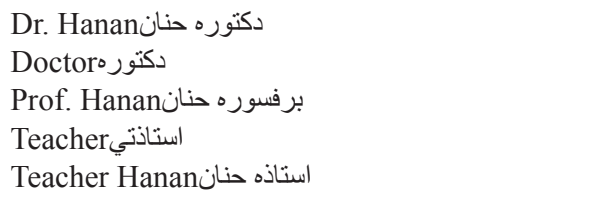 \\
\hline 2 & $\begin{array}{l}\text { Your sister } \\
\text { Cristina }\end{array}$ & 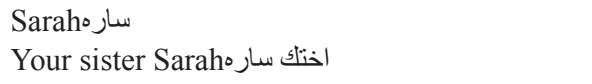 \\
\hline 3 & Abbey & 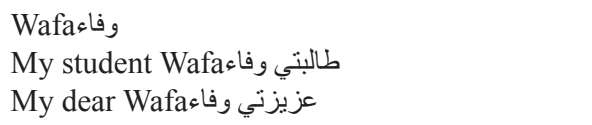 \\
\hline 4 & $\begin{array}{l}\text { Nataly } \\
\text { Girl }\end{array}$ & 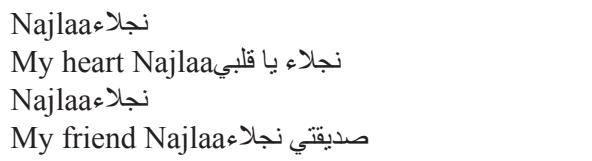 \\
\hline 5 & $\begin{array}{l}\text { Ms. Lisa } \\
\text { Mrs. (last name) } \\
\text { Lisa }\end{array}$ & 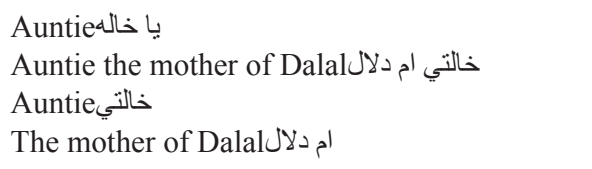 \\
\hline 6 & $\begin{array}{l}\text { Taylor } \\
\text { My sister }\end{array}$ & 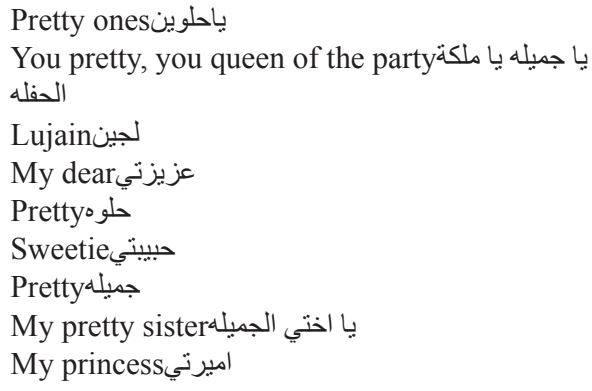 \\
\hline 7 & Melissa & $\begin{array}{l}\text { اخثينهنrathainah } \\
\text { Sister }\end{array}$ \\
\hline 8 & $\begin{array}{l}\text { Professor } \\
\text { My teacher } \\
\text { My friend } \\
\text { Guys }\end{array}$ & 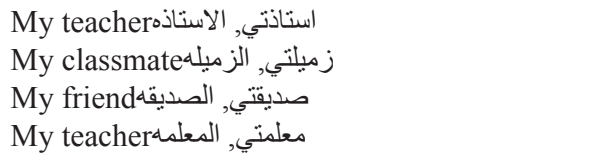 \\
\hline 9 & Rachel & 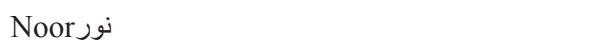 \\
\hline
\end{tabular}

body language and other forms of strategies used for greetings by the AES and SAS groups represented more similarities than differences. These results were derived with the implementation of the relevancy, adjacency and politeness strategies in the required areas with proper justifications for the same. The similarities can be justified with the politeness theory, which focuses on three attributes of rank: imposition; social distance and power relationship. It is when differences between AES and SAS group are low for these parameters, that similarities between their speech acts increase. On the contrary, with a greater gap between these elements of the two groups, the differences in their speech act also become apparent.

\section{Restatement of Findings}

The usage of oral greetings strategies was largely similar between the groups. Similarities between the groups were also found mainly in the use of terms of address and initiation words, with comparatively less similarity being witnessed in their usage of body language and other greeting strategies. The body language of all types, especially wave and smile, were common between both the cultures.

The differences were mostly evident in the usage of the other greeting strategies, as the SAS students used a wide range of other strategies, while the AES respondents to a large extent avoided the use of these strategies. In usage of oral strategies, the dissimilarities were mostly limited to the use of politeness strategies, which were given greater priority by the AES compared to the SAS. Nelson, Carson, Al Batal \& El Bakary (2002) found that the Egyptian Arabic and American English language patterns indicate that they all have the same strategies and the same frequency of making refusals.

Social status was found to have a higher impact on the usage of greeting strategies by the SAS respondents compared to the AES. Moreover, it was found that the increase in formality level reduced the confidence level of the speakers from both groups and a similar situation was evident in case of the social distance. For instance, Nickerson (2000) 
Table 31. Comparative study of the usage of body language

\begin{tabular}{|c|c|c|}
\hline Sit & AES & SAS \\
\hline 1 & $\begin{array}{l}\text { Wave } \\
\text { Smile } \\
\text { Made eye contact while walking } \\
\text { Handshake }\end{array}$ & 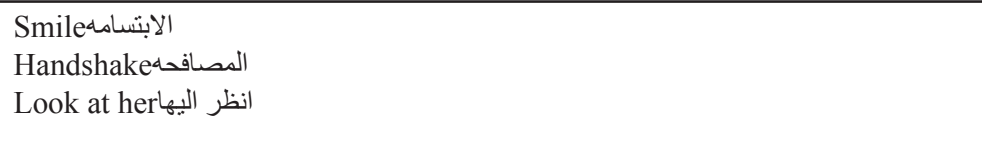 \\
\hline 2 & Smile & 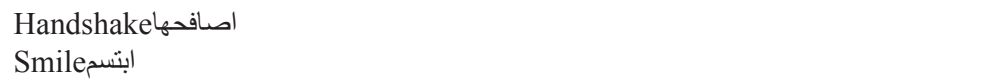 \\
\hline 3 & $\begin{array}{l}\text { Wave } \\
\text { Smile } \\
\text { Light tone } \\
\text { Keep physical distance }\end{array}$ & 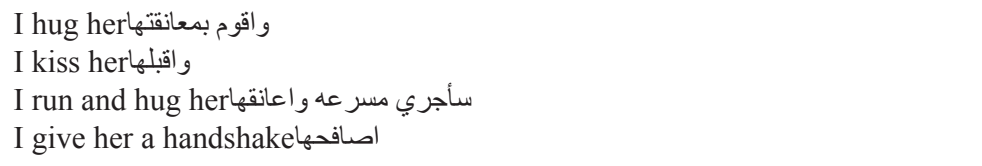 \\
\hline 4 & $\begin{array}{l}\text { Wave } \\
\text { Smile } \\
\text { Run to her } \\
\text { Moving faster towards her but not running } \\
\text { Hug } \\
\text { Catch up }\end{array}$ & 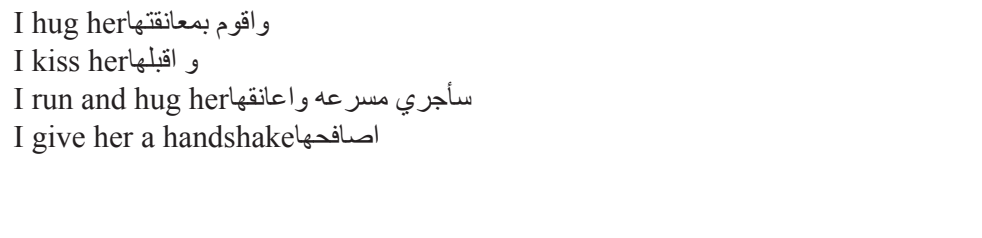 \\
\hline 5 & $\begin{array}{l}\text { Smile } \\
\text { Shake her hand } \\
\text { hug }\end{array}$ & 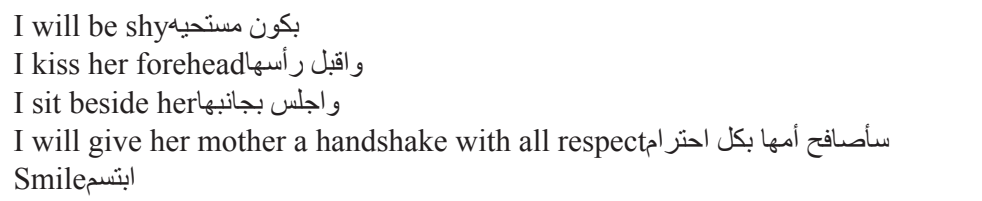 \\
\hline 6 & Smile & 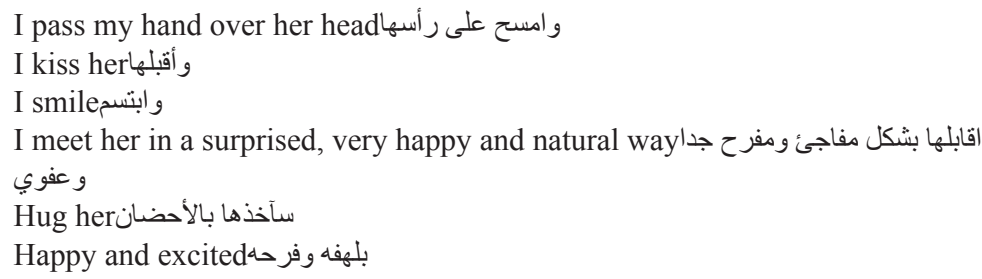 \\
\hline 7 & $\begin{array}{l}\text { Wave } \\
\text { Smile }\end{array}$ & 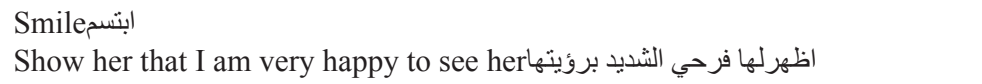 \\
\hline 8 & smile & 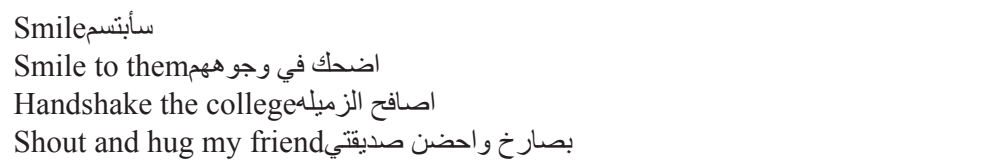 \\
\hline 9 & $\begin{array}{l}\text { Wave } \\
\text { Smile }\end{array}$ & $\begin{array}{l}\text { Smile بسعاده وبشاششه } \\
\text { With happiness and smiling }\end{array}$ \\
\hline
\end{tabular}

adds that the economic situation influences language choice in corporate communication. Influence of the setting on the respondents was minimum owing to the fact that they were surveyed and observed in their normal surroundings. The findings of the study can prove beneficial to linguistics students and EFL teachers, as it reveals the core elements of the speech act causing the differences and similarities that two speaker groups may depict in a social setting. Using these findings, linguistics can understand social perceptions and dogmas in two different socio-cultural groups, while students and EFL teachers can use the findings in their learning process to identify and address their specific learning needs.

\section{REFERENCES}

Ahmad, N. (2015). A study of modes of greetings in a global perspective with particular reference to Urdu speech community in India. MJAL, 7(1), 47-122. http://www. mjal.org/Journal/new/4.pdf.
Al-Hindawi, F. H., Al-Masu'di, H. H., \&Fua'd Mirza, R. (2014). The Speech Act Theory in English and Arabic. Open Journal of Modern Linguistics, 4, 27-37. DOI: 10.4236/ojml.2014.41003.

Al-Khawaldeh, N. (2016). A pragmatic cross-cultural study of complaints expressions in Jordan and England. International Journal of Applied Linguistics and English Literature, 5(5), 197-207. DOI: http://dx.doi.org/10.7575// aiac.ijalel.v.5n.5p.197.

Allott, N. (2013). Relevance theory. Perspectives on Linguistic Pragmatics, 57-98. http://folk.uio.no/nicholea/ papers/Draft_for_Allott,_N._(forthcoming)._Relevance_theory._In_A._Capone,_F._Lo_Piparo_\&_M. Carapezza_(Eds.),_Perspectives_on_Pragmatics_and_ Philosophy._Springer.pdf.

Altbach, P. G. (2002). Perspectives on international higher education. Change: The Magazine of Higher Learning, 34(3), 29-31. http://dx.doi. org/10.1080/00091380209601852. 
Austin, J. (1962). How to Do Things with Words. Oxford: Oxford University Press.

Bach, K. (2003). Speech acts and pragmatics. In Devitt, M. \& Hanley, R. Blackwell. Guide to the philosophy of language (147-167). John Wiley \& Sons.

Bardovi-Harlig, K., \& Mahan-Taylor, R. (2003). Teaching pragmatics. Washington DC: U.S. Department of State Office of English Language Programs. [Online] Available http://exchanges.state.gov/education/engteaching/ pragmatics.htm (May 13, 2010).

Bataineh, R. F. \& Bataineh, R. F. (2008). A cross-cultural comparison of apologies by native speakers of American English and Jordanian Arabic. Journal of Pragmatics, 40, 792-821. https://doi.org/10.1016/j.pragma.2008.01.003.

Blum-Kulka, S. (1982). Learning to say what you mean in a second language: a study of the speech act performance of Hebrew second language learners. Applied Linguistics, III(1), 29-59. DOI: https://doi.org/10.1093/applin/III.1.29.

Buchan, N. R., Johnson, E. J., \& Croson, R. T. (2006). Let's get personal: An international examination of the influence of communication, culture and social distance on other regarding preferences. Journal of Economic Behavior \& Organization, 60(3), 373-398. https://doi. org/10.1016/j.jebo.2004.03.017.

Chierchia, G., Fox, D., \& Spector, B. (2008). The grammatical view of scalar implicatures and the relationship between semantics and pragmatics. Unpublished manuscript. http://isites.harvard.edu/fs/docs/icb.topic720483. files/Chierchia $\% 20$ Fox $\% 20$ and $\% 20$ Spector $\% 20$ embedded\%20SI\%20fin.pdf.

Chowdhury, M. F. (2014). Interpretivism in aiding our understanding of the contemporary social world. Open Journal of Philosophy, 4, 432-438. http://dx.doi.org/10.4236/ ojpp.2014.43047.

Chung, H. H. (2006). Code switching as a communicative strategy: A case study of Korean-English bilinguals. $B i$ lingual research journal, 30(2), 293-307. https://pdfs. semanticscholar.org/7d7a/0c1 f090d21103b961ac4aa3c789774cb843c.pdf.

Coulmas, F. (1981). Introduction: Conversational routine. In Florian Coulmas (Ed.), Conversational Routine: Explorations in Standardized Communication Situations and Pre-Patterned Speech (1-18). The Hague: Mouton.

Flege, J. E. \& Port, R. (1981). Cross-Language Phonetic Interference: Arabic to English. Language and Speech, 24(2), 125-146. http://jimflege.com/files/Flege_Port phonetic_interference_L_S_1981.pdf.

Flege, J. E. (1980). Phonetic Approximation in Second Language Acquisition. Language Learning, 30(1), 117-134.

Fraser, B. (nd). Pragmatic markers. International Pragmatic Association, 6(2), 167-190. DOI: 10.1111/j.14671770.1980.tb00154.x.

Hashemian, M. (2012). Cross-cultural differences and pragmatic transfer in English and Persian refusals. Journal of Teaching Language Skills, 31(3), 23-46. http://jtls. shirazu.ac.ir/article_620_2f7c8c7fe76002f667d85bf65e7a2edb.pdf.
Hua, T. K., Nor, N. F. M., \& Jaradat, M. N. (2012). Communication strategies among EFL students: An examination of frequency of use and types of strategies used. GEMA Online Journal of Language Studies, 12(3), 831-848. https://www.researchgate.net/profile/Kim_Hua_Tan/ publication/287417573_Communication_Strategies_ Among_EFL_Students_-An_Examination_Of_Frequency_Of_Use_And_Types_Of_Strategies_Used/ links/55c2d0a908aebc967defe5f 4 .pdf.

Jalilifar, A. (2009). Request strategies: Cross-sectional study of Iranian EFL learners and Australian native speakers. English Language Teaching, 2(1), 46. http://files. eric.ed.gov/fulltext/EJ1082234.pdf.

Kirdasi, M. I. and Cheng, S. W. (2013). "Hello" or "Salaam?" Greetings by Arabs and Americans. National Chiao Tung University, 1-139. https://ir.nctu.edu.tw/bitstream/11536/72407/1/951101.pdf.

Limberg, H. (2008). Threats in Conflict Talk: Impoliteness and Manipulation. In Impoliteness in Language: Studies on its Interplay with Power in Theory and Practice, ed. by Derek Bousfield and Miriam A. Locher (155-179) K.G.Saur Verlag Germany.

Linguistic Politeness Research Group (Ed.). (2011). Discursive approaches to politeness (Vol. 8). Walter de Gruyter.

Makatchev, M. \& Simmons, R. (2011). Perception of Personality and Naturalness through Dialogues by Native Speakers of American English and Arabic. In Proceedings of the SIGDIAL 2011 Conference, 286-293. https:// arxiv.org/pdf/1105.4582.pdf.

Marquez-Reiter, R. (2000). Linguistic Politeness in Britain and Uruguay. A Contrastive Study of Requests and Apologies. Amsterdam: John Benjamins.

Meiirbekov, A. K., Elikbayev, B. K., Meirbekov, A. K., \& Temirbaev, B. A. (2015). Sociolinguistic Aspects of the speech act of greeting in the Kazakh and English languages. Mediterranean Journal of Social Sciences, 6(6), 267-274. DOI:10.5901/mjss.2015.v6n6s2p267.

Munro, M. J. (1993). Productions of English Vowels by Native Speakers of Arabic: Acoustic Measurements and Accentedness Ratings. Language and Speech, 36(1), 39 - 66. DOI: 10.1177/002383099303600103.

Nelson, G. L., Carson, J., Al Batal, M., \& El Bakary, W. (2002). Cross-cultural pragmatics: Strategy use in Egyptian Arabic and American English refusals. Applied Linguistics, 23(2), 163-189. DOI: https://doi.org/10.1093/applin/23.2.163.

Nickerson, C. (2000). Playing the corporate language game: An investigation of the genres and discourse strategies in English used by Dutch writers working in multinational corporations (Vol. 15). Rodopi.

Sharifian, F. (2004). Cultural schemas and intercultural communication: A study of Persian. In J. Leigh, and E. Loo (Eds.). Outer Limits: A Reader in Communication across Cultures (119-130). Melbourne: CAE Press.

Thorpe, A., Snell, M., Davey-Evans, A., \& Talman, R. (2017). Improving the Academic Performance of Non-native English-Speaking Students: the Contribution of Pre-sessional English Language Programmes. Higher Education Quarterly, 71(1), 5-32. DOI: $10.1111 /$ hequ. 12109. 
Toomnan, P., \& Intaraprasert, C. (2015). The impacts of attitude towards speaking English on the use of communication strategies by English majors in Thailand. Theory and Practice in Language Studies, 5(6), 1151. DOI: http://dx.doi.org/10.17507/tpls.0506.04.

Rababah, G. (2002). Communication Problems Facing Arab Learners of English. ERIC, 1-22.

Vahid Dastjerdi, H., \& Nasri, N. (2012). Congratulation speech acts across cultures: The case of English, Persian, and Arabic. Journal of Language, Culture, and Translation, 1(2), 97-116. http://lct.iaush.ac.ir/pdf_5600_ f8835022a9591bb8eeff962e22a1c5d3.html.

Vilkki, L. (2006). Politeness, Face and Facework: Current Issues. A Man of Measure: Festschrift in Honour of Fred Karlsson, 322-332. http://www.linguistics.fi/julkaisut/SKY2006_1/1.4.7.\%20VILKKI.pdf.

Wagner, L. C. (2004). Positive-and negative-politeness strat- egies: Apologizing in the speech community of Cuernavaca, Mexico. Intercultural Communication Studies, 13, pp. 22-30. http://web.uri.edu/iaics/files/02-Lisa-C.Wagner.pdf.

Waldvogel, J. (2007). Greetings and closings in workplace email. Journal of Computer-Mediated Communication, 12(2), 456-477. DOI: 10.1111/j.10836101.2007.00333.x.

Wei, L. (2010). The Functions and use of greetings. Canadian Social Science, 6 (4), 56-62. https:// www.mysciencework.com/publication/download/b8f8a949f1f0d3fea0936616723d166d/d63eb5e380936bdc1bc2c99507dd1235.

Žegarac, V., \& Pennington, M. C. (2000). Pragmatic transfer in intercultural communication. In Spencer-Oatey, $\mathrm{H}$. Culturally speaking: Managing rapport through talk across cultures (165-190). A\&C Black.

Author Query???

AQ1: Kindly cite Table 6 in text part and also cite all references in chronological order 


\section{APPENDIX A}

\section{Instructions:}

- Please read the following situations carefully.

- Write whatever you would naturally SAY and/or DO in that situation.

- Please write (in English) as much or as little as you feel appropriate for each situation.

1 You are a university student. It is after the break between semesters and the beginning of a new semester, you see your female professor, aged 50-55, while in the University cafeteria. You have not seen each other during break. The cafeteria is not crowded. Your professor's name is Prof. Victoria. You SAY and/or DO:

2 You want to go pick up your friend Christina to go out for lunch. You reach her house and her sister opens the door for you. She is one year younger than you. You have met her once before. Her name is Monica. You SAY and/or DO:......

$\ldots .$.

3 You are an English language school teacher. It is after the break between semesters and the beginning of a new semester. It is the first day of work in the new semester. While walking your way to enter the building, you see your student, a girl which age is 17 , who doesn't notice your presence, and the entrance to the building is not crowded. Last week, your students had an important college entrance exam. You have not seen each other during break. The student's name is Abbey. You SAY and/or DO:

4 You are a university student. It is after the break between semesters and the beginning of a new semester, you see your best friend whom is very nice and the same age as you, while walking on the university campus. You have not seen her during break. Your best friend's name is Nataly. You SAY and/or DO:

5 Your close friend Christina invites you to a party at her house. You ring the bell and she opens the door for you. Her mother is sitting in the living room. Christina walks you there to meet her. You go to the living room and see her mother. Her mother's name is Lisa. You SAY and/or DO?.

6. You made a party for your 10 year old sister. The party started and the doorbell rang. You walk towards the door and open it. It's your sister's friend. Her name is Taylor. You SAY and/or DO:....

7. You run into Mellissa, a classmate with whom you are not very familiar, at a coffee shop. You see her having some milk and sugar from the service table. You SAY and/or DO:

8. You enter your teacher's office to talk to her. While you are at her office, you see one of your classmates sitting there. You haven't seen the teacher and your classmate after the one week vacation you recently had. You SAY and/or DO:...

9. This is your last semester at college. You are a volunteer student/librarian at the university library. Your job is to help students find the books they need. There is a student who usually comes every day. It's only her first semester at the university. It is the first day after the one-week vacation you all came back from. Her name is Rachel. You SAY and/or DO:

$$
\begin{aligned}
& \text { APPENDIX B }
\end{aligned}
$$

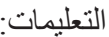

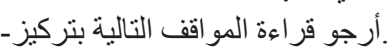

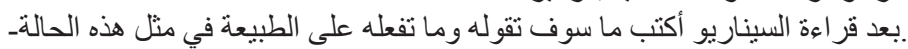

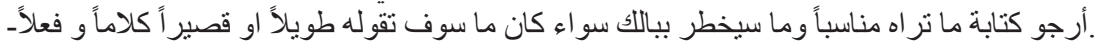

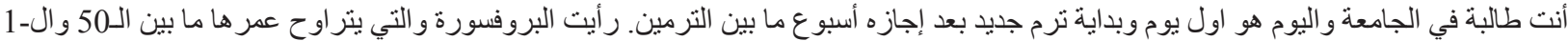

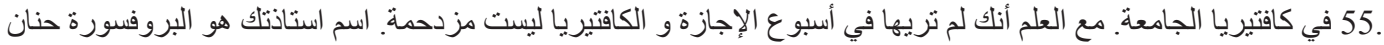

$$
\begin{aligned}
& \text { : موف تقولين/ تفعلين: } \\
& \text { تريدين أن تأخذي صديقتلك سارة من بيتها حتى تذهبين لتناول الغداء معاً. وصلت عند باب البيت وفتحت للك اختها والتي تصغرك بعام واحد. كما أنك قد-2 }
\end{aligned}
$$

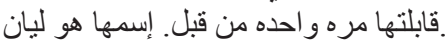

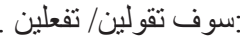




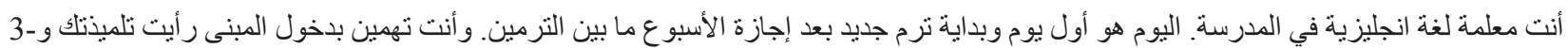

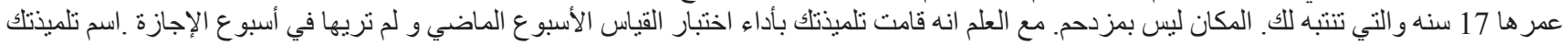

أنت طالبة في الجامعة. اليوم هو أول يو و وبداية ترم جديد بعد إجازة الأسبوع ما بين الترمين. رأيت صديقتلك المقربة للك جدا و التي تعاملك بلطف بالغ-4

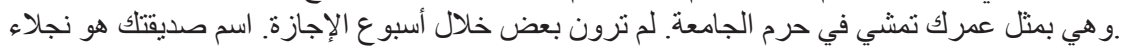
سوف تقولين/ تفعلين

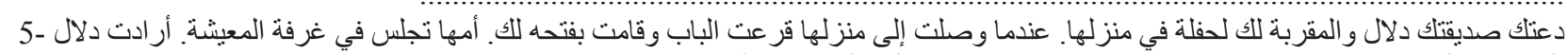

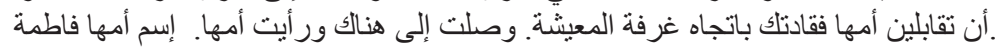
سوف تقولين/ تفعلين

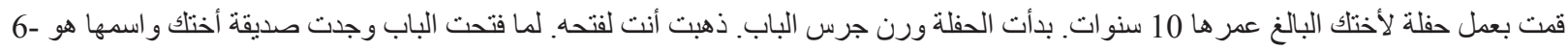

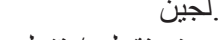

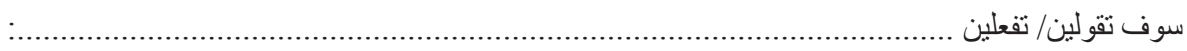
7 قابلت زميلة للك في الصف لا تعرفينها جيداً في إحدى المناسبات واسمها بثينة. رايتها تأخذ طعاماً لها من على طاولة البوفيه

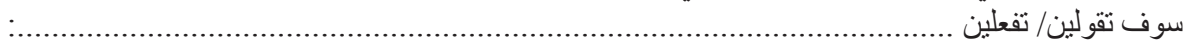

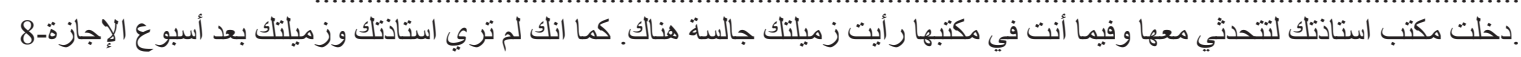

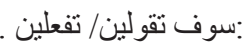

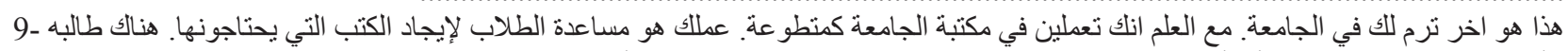

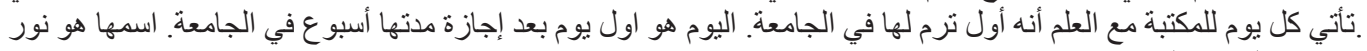
سوف تقولين/ تفعلين 